\title{
Genetic variation and heritability estimation in Jatropha curcas L. progenies for seed yield and vegetative traits
}

\author{
N. Kaushik*, R. P. S. Deswal, Suman Malik and Krishan Kumar \\ CCS HAU Regional Research Station, Bawal - 123501 (Haryana), INDIA \\ *Corresponding author. E-mail: nk20025@rediffmail.com \\ Received: February 3, 2015; Revised received: June 2, 2015; Accepted: July 18,2015.
}

\begin{abstract}
In this study, experiment was conducted on sandy loam soils poor in organic carbon and water holding capacity in southern Haryana, India to determine the best progenies of Jatropha curcas for bio-diesel production. Fifty progenies raised from seed sources collected from nine states of India were evaluated after five years of plantation for growth, seed and oil content traits. The progenies showed significant $(P>0.05)$ differences for all the traits studied. Maximum seed yield/plant (879.37 g), number of capsules/plant (522.67) and plant height $(408.33 \mathrm{~cm})$ was recorded in P-44. Maximum oil content observed in P-37 (36.08\%) followed by P-5 (35.64\%). The magnitude of phenotypic coefficient of variation (PCV) was higher than the corresponding genotypic coefficient of variation (GCV) for all the characters studied. Heritability was highest for oil content $(95.49 \%)$ and 100 -seed weight $(87.75 \%)$ followed by seed yield (75.54\%). Total capsules/plant exhibited highest genetic advance (92.69\%) followed by number of branches per plant $(64.32 \%)$. Hierarchical Euclidean cluster analysis of all 50 progenies using $D^{2}$ statistics was done where the $D^{2}$ analysis grouped the progenies into five clusters. The intra cluster distances ranged from 1.33 to 2.72 . The maximum inter-cluster distance was observed between cluster II and $\mathrm{V}$ (6.43) followed by $\mathrm{I}$ and $\mathrm{V}$ indicating greater divergence among progenies belonging to these clusters and an attempt to cross the progenies in these clusters should bring out desirable gene combinations. These progenies showed considerable potential which can be tapped for planting and selecting the improved varieties.
\end{abstract}

Keywords: Genotypic coefficient, Heritability, Jatropha curcas, Oil content, Phenotypic coefficient, Seed yield

\section{INTRODUCTION}

Feedstock demand for bio-diesel production has received much attention in recent past due to blending requirements of diesel adopted by many countries (Rajgopal and Zilber-man, 2007). European Union and India have set targets of 10 and $20 \%$ replacement of transport fossil fuel with bio-diesel by 2020 and 2017, respectively (Rosch and Skarka, 2009;Biswas et al., 2010). In recent years, Jatropha curcas L., a perennial plant belonging to the family Euphorbiaceae has received considerable interest of the researchers as a potential source of biodiesel. Its multipurpose benefits as a source of green manure, soil ameliorator and improve rural economy by generating huge manpower employment during various stages of its cultivation and downstream processing makes it a potential candidate for large-scale plantation on marginal lands (Rao et al., 2008; Sunil et al., 2008; Kheira and Atta, 2009; Mishra, 2009; Behera et al., 2010). However, the current seed yield of Jatropha for production of bio-fuels is inadequate to completely replace fossil fuels (Ruth, 2008). Despite growing advocacy for Jatropha for large-scale cultivation, its systematic yield improvement studies, especially the selection of high yielding genotypes/accessions/ varieties have not been adequately addressed. Success of commercial cultivation of Jatropha is much dependent on use of high yielding genotypes instead of low -yielding genotypes; therefore genetic improvement of this crop is quite indispensable to develop high -yielding genotypes. Selection/development of high yielding genotypes depends on the genetic variability present in the gene pool (Das et al., 2010). Rao et al. (2008) reported variability observed in Central India which was mainly limited to seed source variation in morphology, germination and seedling growth. Kaushik et al. (2007) have reported divergence in seed oil traits of from a limited number of locally collected accessions. Since heritability estimate in perennial plants decrease with age because of compounded environmental effects making genotypic differences, there is an urgent need for the knowledge of these estimates in the progenies (Rao et al., 2008). However, one of the limitations to this conventional breeding program work is the wide genetic diversity, which has to be evaluated before selection of suitable accessions could be possible. Also breeding of high yielding variety is not possible without knowing the extent of variation that exists among the available germplasm in India, the growth, yield and extent of environmental influence on these factors, heritability and genetic gain of the material (Rafil et al., 2012). Therefore, the present work was undertaken to evaluate 
the 50 accessions of $J$. curcas in India with the aim of selection for future breeding program.

\section{MATERIALS AND METHODS}

Study site: The experiment was conducted at Chaudhary Charan Singh Haryana Agricultural University Regional Research Station, Bawal located in the low rainfall zone of India $\left(28.1^{\circ} \mathrm{N}, 76.5^{\circ} \mathrm{E}\right.$ and $266 \mathrm{~m}$ above mean sea level). The site is characterized by inadequate precipitation $(300-550 \mathrm{~mm})$ during monsoon (July - September). Not only the quantum of rains received during monsoon and winter season is inadequate, but its temporal distribution is also quite erratic. During experimentation, the maximum temperature reached as high as $46^{\circ} \mathrm{C}$. Whereas, during peak winter months of December and January, the average minimum temperature was recorded around $2{ }^{\circ} \mathrm{C}$ some times it reaches as low as $0^{\circ} \mathrm{C}$. Between October and March, weather was almost dry except occasional light showers. Thereafter, it was quite dry till June. High temperature along with peak evapo-transpiration rate of $5.3 \mathrm{~mm} /$ day was observed from July to October and $2.7 \mathrm{~mm} /$ day from November to February.

Plantation material and treatments: Seeds from dry matured fruits were collected from morphologically superior candidate plus trees occurring in wild conditions as well as from designated research farms from 9 states of India (details of the states is given in Table 1) during 2005-2006 under National Networking Programme on Jatropha. The seeds were separated from fruits manually. The seeds were sown in 200 gauge polythene bags (size 9" $\times 6$ ") filled with mixture of sand, soil and Farm Yard Manure (FYM) in the ration of 1:1:1 during the last week of March, 2005 at Regional Research Station, Bawal (Haryana). After 3 months, at the beginning of the rainy season and when appropriate soil moisture levels were reached in the field the seedlings were transplanted at a spacing of 4 $\times 2 \mathrm{~m}$. The experiment was conducted in a randomized block design with three replications. Twenty grams urea, $120 \mathrm{~g}$ single super phosphate and $16 \mathrm{~g}$ murate of potash was applied in the planting pit, optimum soil moisture was considered as a criteria for fertilizer application as it was basically a dry land crop. Besides chemical fertilizers, $2 \mathrm{~kg}$ farm yard manure was applied per pit at the time of planting. Two irrigations were applied during the first year after that plants were not irrigated. Pruning was done between 150 and 180 days after planting on top of all plants at $20 \mathrm{~cm}$. The top was cut off cleanly so as the main stem can produce 5-6 side branches. The plantation was under observation and hoeing and weeding along with pruning were carried out every year. After five years of plantation, observations on plant height $(\mathrm{cm})$, collar diameter (cm), number of primary branches/plant, number of secondary branches/plant, number of flowering branches/plant, number of flowering bunches/plant, number of female flowers/bunch, number of fruits/ bunch, number of fruits/plant, number of seeds/fruit, 100 seed weight and seed yield/plant were recorded on 5 random competitive plants/plot. The data on the 12 traits was analyzed in randomized block design (RBD) after Panse and Sukhatme (1978).

Genotypic and phenotypic Coefficients of variations were estimated by the formula suggested by Burton (1952) for each character as follows:

Genotypic coefficient of variance $=\frac{\sqrt{ } \sigma^{2} \mathrm{~g} \times 100}{\mathrm{X}}$

Where $\mathrm{X}$ was mean of that particular character

Heritability in broad sense was calculated according to the formula suggested by Johnson et al. (1955) for each character.

Heritability (broad sense) in percent $=h^{2}=\frac{\sigma^{2} g}{\sigma^{2} p} \times 100$ Where:

$\sigma^{2} \mathrm{~g}=$ Genotypic variance

$\sigma^{2} \mathrm{p}=$ Phenotypic variance

Estimates of appropriate variance components were substituted for the parameters to predict the expected genetic gain as suggested by Lush (1949). The expected genetic gain was calculated at $5 \%$ selection intensity for each character as:

Genetic advance $(\%)$ of mean $=\frac{K \cdot \sigma p \cdot h^{2}}{X}$

Where:

$\mathrm{K}=$ selection differential (2.06)

$\sigma \mathrm{p}=$ phenotypic standard deviation

$\mathrm{h}^{2}=$ heritability in broad sense

$\mathrm{X}=$ general mean

The genetic divergence was calculated by using non - hierarchical Euclidian cluster analysis (Spark, 1973)

\section{RESULTS AND DISCUSSION}

The analysis of data on growth and oil content traits for different accessions/progenies of Jatropha after 5 years of plantation showed significant $(\mathrm{P}<0.05)$ differences (Table 1). The plant height varied from 283.33 to $408.33 \mathrm{~cm}$ with mean value $340.68 \pm 18.03$ $\mathrm{cm}$. Maximum plant height $(408.33 \mathrm{~cm})$ was recorded in P-37 followed by P-44 $(393.33 \mathrm{~cm})$. The 100 -seed weight showed less variability. It ranged from 45.73 to $81.83 \mathrm{gm}$. The minimum 100-seed weight was recorded in P- 25 (45.73 gm) followed by P-19 (45.90 gm) whereas maximum in P-46 (81.83 gm). The seed yield per plant showed large variation as compared to 100 -seed weight. It ranges from 33.73 to $879.37 \mathrm{gm}$ with mean value of $272.99 \pm 76.64$ gm. Maximum seed yield/plant was recorded in P-44 (879.37) followed by P-47 (851.63). The number of branches per plant varied from 21.67 to 183.33 affecting number of other traits under study. Average number of 
Table 1. Mean values for seed yield, oil content and growth characters in J. curcas.

\begin{tabular}{|c|c|c|c|c|c|c|c|c|c|c|c|}
\hline $\begin{array}{l}\text { Prog- } \\
\text { eny } \\
\text { num- } \\
\text { ber }\end{array}$ & State & $\begin{array}{l}100 \\
\text { Seed } \\
\text { weight. }\end{array}$ & $\begin{array}{l}\text { Seed } \\
\text { yield/ } \\
\text { plant }\end{array}$ & $\begin{array}{l}\text { No. of } \\
\text { branche } \\
\text { s/plant }\end{array}$ & $\begin{array}{l}\text { Plant } \\
\text { height }\end{array}$ & $\begin{array}{l}\text { No. of } \\
\text { fruiting } \\
\text { branche } \\
\text { s/plant }\end{array}$ & $\begin{array}{l}\text { Crown } \\
\text { spread }\end{array}$ & $\begin{array}{l}\text { Total } \\
\text { cap- } \\
\text { sules/ } \\
\text { plant }\end{array}$ & $\begin{array}{l}\text { Aver- } \\
\text { age no. } \\
\text { of } \\
\text { bunches } \\
\text { /plant }\end{array}$ & $\begin{array}{l}\text { Oil } \\
\text { content }\end{array}$ & $\begin{array}{l}\text { Seed } \\
\text { Yield } \\
\text { (Q/ } \\
\text { ha.) }\end{array}$ \\
\hline 1 & Maharashtra & 65.60 & 210.13 & 123.00 & 343.33 & 31.33 & 383.33 & 310.00 & 1.37 & 30.87 & 2.63 \\
\hline 2 & Maharashtra & 59.70 & 172.03 & 98.00 & 296.67 & 22.00 & 355.00 & 287.50 & 1.83 & 31.07 & 2.15 \\
\hline 3 & Maharashtra & 58.07 & 42.17 & 85.00 & 330.00 & 10.00 & 309.17 & 75.00 & 1.56 & 30.00 & 0.53 \\
\hline 4 & Uttrakhand & 60.53 & 61.27 & 114.33 & 328.33 & 17.00 & 354.17 & 104.17 & 1.13 & 32.77 & 0.77 \\
\hline 5 & Uttrakhand & 60.23 & 61.23 & 141.33 & 340.00 & 17.00 & 365.83 & 100.83 & 1.23 & 35.64 & 0.70 \\
\hline 6 & Chhattisgarh & 53.83 & 101.47 & 122.33 & 283.33 & 25.00 & 356.67 & 188.33 & 1.17 & 27.79 & 1.27 \\
\hline 7 & Chhattisgarh & 50.80 & 174.13 & 106.33 & 326.67 & 29.00 & 364.17 & 327.50 & 1.50 & 18.04 & 2.18 \\
\hline 8 & Chhattisgarh & 59.90 & 75.23 & 88.33 & 308.33 & 14.33 & 300.00 & 127.50 & 1.30 & 27.55 & 0.94 \\
\hline 9 & Madhya Pradesh & 52.80 & 141.53 & 105.67 & 336.67 & 20.67 & 330.00 & 262.50 & 1.67 & 21.88 & 1.77 \\
\hline 10 & Madhya Pradesh & 58.83 & 123.60 & 124.00 & 336.67 & 27.00 & 377.50 & 207.50 & 1.13 & 19.96 & 1.55 \\
\hline 11 & Tamil Nadu & 61.50 & 111.87 & 102.00 & 283.33 & 21.33 & 339.17 & 182.50 & 1.23 & 23.22 & 1.40 \\
\hline 12 & Tamil Nadu & 58.20 & 82.50 & 107.33 & 333.33 & 14.67 & 327.50 & 139.17 & 1.57 & 26.36 & 1.03 \\
\hline 13 & Tamil Nadu & 55.45 & 96.53 & 102.00 & 300.00 & 12.67 & 325.00 & 166.67 & 1.63 & 23.49 & 1.21 \\
\hline 14 & Tamil Nadu & 62.60 & 135.83 & 97.00 & 301.67 & 16.67 & 369.17 & 220.00 & 1.43 & 23.46 & 1.70 \\
\hline 15 & Tamil Nadu & 60.70 & 99.47 & 86.33 & 326.67 & 17.00 & 323.33 & 165.83 & 1.26 & 22.89 & 1.24 \\
\hline 16 & Tamil Nadu & 72.70 & 312.03 & 131.33 & 356.67 & 36.33 & 441.67 & 429.17 & 1.53 & 26.41 & 3.90 \\
\hline 17 & Rajasthan & 63.50 & 101.37 & 87.00 & 355.00 & 24.00 & 330.00 & 161.00 & 1.13 & 17.40 & 1.27 \\
\hline 18 & Rajasthan & 58.93 & 139.77 & 91.33 & 341.67 & 25.33 & 326.67 & 123.67 & 1.23 & 30.10 & 1.75 \\
\hline 19 & Rajasthan & 45.90 & 71.13 & 99.67 & 325.00 & 14.33 & 329.17 & 126.03 & 1.53 & 23.63 & 0.89 \\
\hline 20 & Rajasthan & 46.80 & 60.33 & 110.00 & 335.00 & 13.00 & 310.00 & 100.67 & 1.27 & 15.23 & 0.75 \\
\hline 21 & Rajasthan & 48.90 & 36.43 & 111.00 & 326.67 & 10.67 & 310.83 & 87.67 & 1.27 & 18.16 & 0.46 \\
\hline 22 & Gujarat & 48.07 & 40.90 & 95.33 & 350.00 & 10.33 & 303.33 & 104.00 & 1.27 & 20.08 & 0.51 \\
\hline 23 & Gujarat & 47.07 & 33.73 & 91.67 & 340.00 & 10.67 & 305.00 & 98.67 & 1.33 & 17.44 & 0.51 \\
\hline 24 & Gujarat & 47.23 & 42.33 & 93.67 & 326.67 & 9.33 & 336.67 & 102.33 & 1.23 & 15.13 & 0.53 \\
\hline 25 & Gujarat & 45.73 & 43.23 & 70.00 & 310.00 & 8.67 & 280.83 & 97.00 & 1.27 & 15.23 & 0.54 \\
\hline 26 & Gujarat & 50.00 & 35.97 & 87.67 & 320.00 & 8.00 & 332.50 & 78.67 & 1.17 & 15.97 & 0.45 \\
\hline 27 & Gujarat & 50.13 & 53.63 & 97.33 & 315.00 & 8.67 & 306.67 & 103.33 & 1.73 & 25.25 & 0.67 \\
\hline 28 & Gujarat & 53.40 & 60.20 & 90.33 & 333.33 & 9.33 & 275.00 & 105.33 & 1.27 & 15.13 & 0.75 \\
\hline 29 & Punjab & 52.23 & 85.20 & 102.00 & 331.67 & 11.00 & 318.33 & 154.67 & 1.07 & 20.34 & 1.06 \\
\hline 30 & Haryana & 58.40 & 136.83 & 126.67 & 363.33 & 15.33 & 388.33 & 184.67 & 1.17 & 15.91 & 1.71 \\
\hline 31 & Haryana & 79.13 & 572.17 & 44.33 & 373.33 & 21.0 & 380.83 & 289.33 & 1.90 & 31.60 & 7.20 \\
\hline 32 & Haryana & 77.30 & 470.23 & 34.67 & 355.00 & 44.0 & 360.00 & 243.33 & 1.97 & 31.46 & 5.90 \\
\hline 33 & Haryana & 64.60 & 225.57 & 21.67 & 368.33 & 27.3 & 340.00 & 139.67 & 2.00 & 28.18 & 2.80 \\
\hline 34 & Haryana & 75.40 & 327.37 & 26.00 & 365.00 & 35.0 & 315.83 & 173.67 & 1.93 & 32.57 & 4.10 \\
\hline 35 & Haryana & 73.77 & 482.20 & 43.33 & 348.33 & 28.3 & 368.33 & 261.33 & 1.70 & 29.36 & 6.03 \\
\hline 36 & Haryana & 75.67 & 591.87 & 43.33 & 370.00 & 34.3 & 367.50 & 315.67 & 1.96 & 33.03 & 7.40 \\
\hline 37 & Haryana & 74.50 & 576.77 & 54.67 & 408.33 & 30.3 & 355.00 & 309.67 & 1.60 & 36.08 & 7.20 \\
\hline 38 & Haryana & 74.47 & 484.47 & 47.33 & 356.67 & 43.3 & 359.17 & 256.67 & 1.63 & 31.16 & 6.10 \\
\hline 39 & Haryana & 75.67 & 685.73 & 47.00 & 371.67 & 39.7 & 375.00 & 362.33 & 2.07 & 24.16 & 8.60 \\
\hline 40 & Haryana & 75.37 & 332.40 & 35.67 & 358.33 & 33.7 & 315.83 & 176.33 & 1.57 & 24.19 & 4.20 \\
\hline 41 & Haryana & 73.87 & 356.57 & 37.67 & 350.67 & 28.7 & 334.17 & 193.00 & 1.43 & 29.19 & 4.50 \\
\hline 42 & Haryana & 74.87 & 598.57 & 35.67 & 286.67 & 26.0 & 326.67 & 319.67 & 2.60 & 32.80 & 7.50 \\
\hline 43 & Haryana & 76.50 & 347.47 & 31.33 & 341.67 & 23.3 & 344.17 & 181.67 & 1.60 & 29.86 & 4.30 \\
\hline 44 & Haryana & 67.30 & 879.37 & 64.33 & 393.33 & 46.7 & 405.00 & 522.67 & 2.07 & 28.50 & 11.00 \\
\hline 45 & Haryana & 77.40 & 645.67 & 50.00 & 375.00 & 34.0 & 408.33 & 333.67 & 1.97 & 26.17 & 8.10 \\
\hline 46 & Haryana & 81.83 & 603.97 & 34.67 & 360.00 & 28.3 & 333.33 & 295.33 & 2.40 & 30.09 & 7.50 \\
\hline 47 & Haryana & 79.10 & 851.63 & 53.67 & 370.00 & 28.3 & 440.00 & 430.67 & 2.27 & 30.45 & 10.60 \\
\hline 48 & Haryana & 75.07 & 513.20 & 46.00 & 373.33 & 21.0 & 353.33 & 273.33 & 1.80 & 35.33 & 6.40 \\
\hline 49 & Haryana & 73.87 & 483.43 & 32.33 & 353.33 & 44.0 & 400.00 & 261.67 & 2.17 & 24.62 & 6.03 \\
\hline 50 & Haryana & 76.60 & 678.57 & 41.67 & 350.00 & 27.3 & 401.67 & 354.33 & 2.50 & 28.43 & 8.50 \\
\hline $\mathrm{P}>0.05$ & & 6.64 & 215.41 & 37.80 & 50.70 & 15.96 & 69.05 & 152.05 & 0.66 & 1.50 & 1.67 \\
\hline S E (d) & & 3.43 & 108.38 & 19.01 & 25.51 & 8.03 & 34.74 & 76.50 & 0.33 & 0.76 & 0.84 \\
\hline $\mathrm{S} E(\mathrm{~m})$ & & 2.36 & 76.64 & 13.45 & 18.03 & 5.68 & 24.56 & 54.09 & 0.24 & 0.53 & 0.59 \\
\hline $\mathrm{C} \mathrm{V}$ & & 6.46 & 48.62 & 29.76 & 9.17 & 36.81 & 12.25 & 48.48 & 25.73 & 3.61 & 30.13 \\
\hline
\end{tabular}


Table 2. Heritability (BS) genetic advance (\%) of mean and co-efficient of variation in J. curcas.

\begin{tabular}{lcccc}
\hline Source & Heritability (\%) & $\begin{array}{c}\text { Genetic advance } \\
\text { as (\%) of mean }\end{array}$ & \multicolumn{2}{c}{ Co-efficient of Variation (\%) } \\
\hline 100 -seed weight & 87.75 & 33.34 & Phenotypic & Genotypic \\
Seed Yield/Plant & 75.54 & 53.02 & 18.45 & 17.28 \\
No. of branches/Plant & 63.47 & 64.32 & 98.32 & 85.46 \\
Plant height & 30.11 & 6.76 & 49.24 & 39.22 \\
No. of fruiting branches/plant & 28.83 & 33.94 & 10.97 & 6.02 \\
Crown spread & 29.64 & 8.91 & 14.61 & 30.68 \\
Total capsules/plant & 59.28 & 92.69 & 75.97 & 58.49 \\
Av. No. of bunches/plant & 36.34 & 24.25 & 32.44 & 19.49 \\
Oil content & 95.49 & 47.60 & 24.19 & 23.64 \\
Seed yield (q/ha.) & 83.14 & 8.60 & 5.02 & 4.75 \\
\hline
\end{tabular}

Table 3. Genotypic and phenotypic correlation of different seed yield, oil content and growth characters in J. curcas.

\begin{tabular}{|c|c|c|c|c|c|c|c|c|c|}
\hline Characters & $\begin{array}{c}\text { Geno- } \\
\text { typic/ } \\
\text { Pheno- } \\
\text { typic }\end{array}$ & $\begin{array}{c}\text { Seed } \\
\text { yield/ } \\
\text { plant }\end{array}$ & $\begin{array}{c}\text { No. of } \\
\text { branches/ } \\
\text { plant }\end{array}$ & $\begin{array}{c}\text { Plant } \\
\text { height }\end{array}$ & $\begin{array}{c}\text { No. of } \\
\text { fruiting } \\
\text { branches/ } \\
\text { plant }\end{array}$ & $\begin{array}{l}\text { Crown } \\
\text { spread }\end{array}$ & $\begin{array}{l}\text { Cap- } \\
\text { sules/ } \\
\text { plant }\end{array}$ & $\begin{array}{l}\text { Av. No. of } \\
\text { bunches/ } \\
\text { plant }\end{array}$ & $\begin{array}{c}\text { Oil } \\
\text { Content }\end{array}$ \\
\hline \multirow{6}{*}{$\begin{array}{l}\text { 100-Seed } \\
\text { weight. } \\
\text { Seed yield/ } \\
\text { plant } \\
\text { No. of } \\
\text { branches/ } \\
\text { plant }\end{array}$} & $\mathrm{G}$ & $0.901^{* *}$ & $-0.805^{* *}$ & $0.722^{* *}$ & $0.710^{* * *}$ & $0.780^{* *}$ & $0.802^{* *}$ & $0.907^{* *}$ & $0.709 * *$ \\
\hline & $\mathrm{P}$ & $0.749^{* *}$ & $-0.593^{* *}$ & $0.430^{* *}$ & $0.365^{* *}$ & $0.373^{* *}$ & $0.602^{* *}$ & $0.468^{* *}$ & $0.659 * *$ \\
\hline & G & & $-0.842^{* *}$ & $0.760^{* *}$ & $0.493^{* *}$ & $0.758^{* *}$ & $0.840^{* *}$ & $1.000^{* *}$ & $0.575 * *$ \\
\hline & $\mathrm{P}$ & & $-0.513^{* *}$ & $0.529^{* *}$ & $0.375^{* *}$ & $0.539^{* *}$ & $0.842^{* *}$ & $0.638^{* *}$ & $0.486^{* *}$ \\
\hline & G & & & $-0.813^{* *}$ & $-0.223^{* *}$ & $-0.327^{* *}$ & $-0.513^{* *}$ & $-0.860^{* *}$ & $-0.444^{* *}$ \\
\hline & $\mathrm{P}$ & & & $-0.182^{*}$ & $0.131^{\mathrm{NS}}$ & $0.132^{\mathrm{NS}}$ & $-0.191^{*}$ & $-0.580^{* *}$ & $-0.354^{* *}$ \\
\hline \multirow{2}{*}{ Plant height } & G & & & & $0.293^{* *}$ & $0.537^{* *}$ & $0.427^{* *}$ & $0.568^{* *}$ & $0.402^{* *}$ \\
\hline & $\mathrm{P}$ & & & & $0.333^{* *}$ & $0.354^{* *}$ & $0.409^{* *}$ & $0.187^{*}$ & $0.209^{*}$ \\
\hline \multirow{2}{*}{$\begin{array}{l}\text { No. of fruit- } \\
\text { ing } \\
\text { branches/ } \\
\text { plant }\end{array}$} & G & & & & & $0.723^{* *}$ & $0.700^{* *}$ & $0.335^{* *}$ & $\begin{array}{l}0.556^{* *} \\
0.272^{* *}\end{array}$ \\
\hline & $\mathrm{P}$ & & & & & $0.398^{* *}$ & $0.571^{* *}$ & $0.118^{\mathrm{NS}}$ & \\
\hline Crown & G & & & & & & $0.948^{* *}$ & $0.726^{* *}$ & $0.494^{* *}$ \\
\hline spread & $\mathrm{P}$ & & & & & & $0.636^{* *}$ & $0.180^{*}$ & $0.232^{* *}$ \\
\hline \multirow{2}{*}{$\begin{array}{l}\text { Total cap- } \\
\text { sules/plant }\end{array}$} & G & & & & & & & $0.858^{* *}$ & $0.585^{* *}$ \\
\hline & $P$ & & & & & & & $0.525 * *$ & $0.436^{* *}$ \\
\hline Average no. & G & & & & & & & & $0.633^{* *}$ \\
\hline $\begin{array}{l}\text { of bunches/ } \\
\text { plant }\end{array}$ & $\mathrm{P}$ & & & & & & & & $0.387^{* *}$ \\
\hline
\end{tabular}

Table 4. Clustering for genetic divergence in seed yield, oil content and growth characters of $J$. curcas.

\begin{tabular}{lcll}
\hline Clusters & No. of progenies in cluster & progenies & \\
\hline Cluster I & 2 & 1,16 & \\
Cluster II & 12 & $36,48,32,31,37,46,39,49,50,44,47$ & \\
Cluster III & 8 & $33,34,35,38,43,40,41,42$ & \\
Cluster IV & 19 & $3,8,12,15,13,19,27,4,5,11,14,6,2,7, \quad 10,9,17,18,30$ \\
Cluster V & 9 & $20,21,29,22,23,24,26,25,28$ & \\
\hline
\end{tabular}

branches per plant was $78.27 \pm 13.45$. Maximum number of branches per plant was observed in P-5 (141.33). As number of branches per plant showed large variation also affected average number of fruiting branches per plant. It varies from 8.00 to 64.33 with mean value $26.72 \pm 5.68$. Maximum number of fruiting branches per plant was observed in P-44 whereas minimum in $\mathrm{P}$ -26 (8.00). Minimum crown spread was recorded in P-28 (275.00) and maximum in P-26(441.67) with mean value of $347.18 \pm 24.56$. Total number of capsules varied from 27.67 to 522.67 with average values of $193.26 \pm 54.09$. Maximum capsules were also observed in P-44 whereas minimum in P-3. Average number of branches varied from 1.06 to 2.60 with mean value of $1.59 \pm 0.24$. Oil content \% varied from 15.13 to 36.06 with mean value of $25.67 \pm 0.53$. Maximum oil content observed in P-37 (36.08) followed by P-5 (35.64). Minimum oil content was observed in P-24, P-28 (15.13) followed by P-20 (15.23). Seed yield q/ha varies from 0.45 to $11.00 \mathrm{q}$ with mean value of $3.41 \pm 0.59$. Maximum seed yield $\mathrm{q} / \mathrm{h}$ a was recorded in P-44 (11.00 q) whereas minimum P-26 (0.45 q). From above mean performance it is clear that $\mathrm{P}-44$ is superior progeny among others under study. 
Table 5. Intra and inter cluster distances for seed yield, oil content and growth characters in J. curcas.

\begin{tabular}{lccccc}
\hline Clusters & Cluster I & Cluster II & Cluster III & Cluster IV & Cluster V \\
\hline Cluster I & $\mathbf{2 . 3 2}$ & 4.36 & 4.88 & 4.35 & 6.01 \\
Cluster II & & $\mathbf{2 . 7 2}$ & 3.41 & 5.25 & 6.43 \\
Cluster III & & $\mathbf{2 . 6 0}$ & 4.12 & 4.90 \\
Cluster IV & & & $\mathbf{2 . 7 0}$ & 3.13 \\
Cluster V & & & & $\mathbf{1 . 3 3}$ \\
\hline
\end{tabular}

Table 6. Cluster mean values for seed yield, oil content and growth characters in J. curcas.

\begin{tabular}{lccccccccc}
\hline Clusters & $\begin{array}{c}\text { 100- } \\
\text { Seed } \\
\text { weight }\end{array}$ & $\begin{array}{c}\text { Seed } \\
\text { yield/ } \\
\text { plant }\end{array}$ & $\begin{array}{c}\text { No. of } \\
\text { branches/ } \\
\text { plant }\end{array}$ & $\begin{array}{c}\text { Plant } \\
\text { height }\end{array}$ & $\begin{array}{c}\text { No. of } \\
\text { fruiting } \\
\text { branches/ } \\
\text { plant }\end{array}$ & $\begin{array}{c}\text { Crown } \\
\text { spread }\end{array}$ & $\begin{array}{c}\text { Total } \\
\text { capsules/ } \\
\text { plant }\end{array}$ & $\begin{array}{c}\text { Average no. } \\
\text { of bunches/ } \\
\text { plant }\end{array}$ & $\begin{array}{c}\text { Oil } \\
\text { Con- } \\
\text { tent }\end{array}$ \\
\hline Cluster I & 69.15 & 261.08 & 127.17 & 350.00 & 33.83 & 412.50 & 369.58 & 1.45 & 28.62 \\
Cluster II & 76.12 & 629.38 & 45.56 & 371.11 & 23.19 & 381.67 & 332.67 & 2.06 & 29.99 \\
Cluster III & 73.60 & 394.33 & 34.83 & 346.99 & 16.75 & 338.02 & 212.75 & 1.81 & 29.67 \\
Cluster IV & 57.37 & 104.30 & 104.32 & 322.72 & 18.53 & 340.92 & 152.00 & 1.39 & 25.08 \\
Cluster V & 48.83 & 48.70 & 94.63 & 330.37 & 10.11 & 308.06 & 38.00 & 1.24 & 16.99 \\
\hline
\end{tabular}

All the parameters studied exhibited considerable amount of variation in the progenies. Plant height and number of branches are important characters that can be looked upon as major selection indices when the objective is to incorporate Jatropha in agro-forestry systems wherein balanced trade off can be made on yield considering the economic potential of the understory crop in the initial years of establishment. On the other hand the variation observed in reproductive characters can be useful in selecting plant types for block plantations with high yield as the primary objective. Significant differences in plant height, collar diameter, secondary branches per plant, flowering branches per plant, female flowers per bunch and seed yield, excepting primary branches/plant, fruits/bunch and seeds/fruit were reported by Das et al. (2010) in J. curcas. Biabani et al. (2012) also reported variability in growth, yield and yield components of $J$. curcas. Nath et al. (2014) reported significant differences for number of secondary branches per plant, oil content, number of fruits per plant, number of clusters per plant in $J$. curcas.

Seed oil content variation has been reported in Jatropha curcas (Kaushik et al., 2007; Rao et al., 2008; Das et al., 2010 Singh et al., 2013 and Nath et al., 2014). Oil content (\%) had significant variation among the accessions in the germplasm used for this study. The results are in agreement with the findings of Freitas et al. (2011) which stated that variation was observed in the oil content in different $J$. curcas populations. The extent of variability is also assessed by genotypic and phenotypic coefficient of variation. The magnitude of PCV was higher than the corresponding GCV for all the characters studied though they were only small differences (Table 2). In the present study maximum phenotypic and genotypic coefficient of variation was observed for seed yield/plant (98.32 and 85.46) followed by total capsules/plant (75.97, 58.49), respectively.

The relative values of PCV, GCV gave an idea about the magnitude of variability present in a genetic population. Estimates of GCV were less than PCV for many traits indicating the role of environment in selection for genetic improvement. The variability parameter estimates in the study are in close approximation with the findings of genetic parameters in $J$. curcas (Das et al., 2010; Singh et al., 2013 and Nath et al., 2014).

Estimation of broad sense heritability for different characters showed that heritability was highest for oil content $(95.49 \%)$ and 100 -seed weight $(87.75 \%)$ followed by seed yield $(75.54 \%)$ and number of branches per plant $(63.47 \%)$. Lowest heritability was recorded for number of fruiting branches/plant (Table 2). Total capsules/plant exhibited highest genetic advance $(92.69 \%)$ followed by number of branches per plant $(64.32 \%)$. Genetic advance as percentage of mean was high $(>50 \%)$ for total number of capsules per plant $(92.69 \%)$ followed by seed yield/plant $(71.6 \%)$ and number of branches /plant, moderate (30 $-50 \%$ ) for oil content, number of fruiting branches and 100 -seed weight and low for other traits.

The phenotypic correlation estimates among the 9 traits ranged from 0.593 to 0.659 (Table 3 ). All the 8 component traits, except no. of branches/plant showed positive correlation with yield and among themselves but the magnitude of association varied. Plant height, number of fruiting branches/plant, crown spread, total capsules/plant, average no. of bunches/plant and oil content showed significant positive correlation with seed yield/plant, whereas, Number of branches/plant showed significant and negative correlation. Similar trend was observed for genotypic correlation.

Heritability estimates in the broad sense were found to be high $(>80 \%)$ for plant height, fruits/plant and 100 seed weight, oil content and seed yield. Hence these characters can be viewed as best gain characteristics for Jatropha improvement more so because of its strong genetic control and a wide range of variability. Studies on 32 CPTs of $J$. curcas revealed that the traits female: male flower ratio, seed yield and plant height had high broad sense heritability (Rao et al., 2008). 
High heritability was also reported for plant height, fruits per plant and collar diameter in J. curcas (Das et al., 2010). Genetic advance as percentage of mean was high $(>50 \%)$ for the traits seed yield/plant, number of branches/plant and total capsules/plant. Estimates of heritability along with genetic advance have a crucial role in tree improvement, as it provides an index of the relative role of heredity and environment in the expression of various traits. In this study, moderate to high heritability accompanied with high GA for seed yield/plant, number of branches/plant and total capsule/plant indicated that heritability was due to additive gene action and selection for these characters may be effective. However, it should be noted that estimation of heritability is of little significance in coherent selection breeding programs unless accompanied by sufficient genetic gain (Tefera et al., 2003). Due to large differences in the phenotypic variation between different traits, genetic advance is not directly related to heritability values. In the present study, moderate to high genetic gain values for different characters indicated that improvement could be made in these characters. Genetic advance was considerably larger in the growth and yield traits as compared plant height and crown spread. This could be due to extreme variation in the material investigated, and smaller values for genetic advance are expected in further selection cycles in a more improved material.

Hierarchical Euclidean cluster analysis of all 50 progenies using $\mathrm{D}^{2}$ statistics was done where the $\mathrm{D}^{2}$ analysis grouped the progenies into 5 clusters (Table 4). The highest number of 19 progenies were included in the cluster IV followed by cluster II (12 progenies); clusters I had only 2 . The intra cluster distances ranged from 1.33 to 2.72 with (Table 5) a maximum value falling in cluster II and minimum in cluster V. The maximum inter-cluster distance was observed between cluster II and V (6.43) followed by I and V and minimum was between clusters IV and cluster $\mathrm{V}$ (3.13). The cluster mean also varied among different cluster groups for all traits (Table 6). The highest cluster mean for 100 - seed weight $(76.12 \mathrm{~g})$, seed yield per plant $(629.28 \mathrm{~g})$, plant height $(371.11 \mathrm{~cm})$, average no. of bunches (2.06) and oil content $(29.99 \%)$ was recorded in cluster II while cluster I recorded maximum no. of branches per plant (127.17), no. of fruiting branches per plant (33.83), crown spread (412. 50) and total capsules per plant (369.58).

The variation among the cluster means for the traits studied, indicated the divergent nature of the clusters formed (Table 5). Maximum intra-cluster distance (2.72) shown by cluster II indicates wide divergence with in cluster itself which may be due to environmental factors and thus, suggests that selection of parents for hybridization within cluster should be based on genetic diversity rather than geographic diversity. Maximum inter-cluster distance between cluster II and V (6.43) followed by cluster I and V (6.01) indicates greater divergence between genotypes belonging to these clusters and an attempt to cross the progenies in these clusters should bring out desirable gene combinations. The lowest inter cluster distance observed between clusters $\mathrm{IV}$ and $\mathrm{V}$ suggested that seed sources originating from these clusters were not genetically much diverse and thus, selection of parents from these clusters should be avoided. Thus, it may be suggested that the crosses between clusters II and V may result sufficient segregation and further progeny selection may help in the improvement of species.

\section{Conclusion}

Considerable differences existed among the progenies for growth, yield and oil content in J. curcas. Progeny number 44, 47 and 37 were found to be the best on basis of most of the characters examined. These progenies showed considerable potential which can be judiciously tapped for planting and selecting the improved varieties. Minute differences between phenotypic coefficient of variation, genotypic coefficient of variation and high estimates of heritability for most of the characters examined revealed the heritable nature of variability. The crosses between clusters II and $\mathrm{V}$ may result sufficient segregation and further progeny selection may help in the improvement of species. Therefore, the progenies belonging to these clusters could be taken as parents for a successful hybridization program.

\section{REFERENCES}

Behera, S.K., P. Srivastava, R. Tripathy, J.P. Singh and Singh, N. (2010). Evaluation of plant performance of Jatropha curcas L. under diferent agro-practices for optimizing biomass -A case study. Biomass and Bioenergy, 34:30-41.

Biabani, Alireza, Mohd Y Rafii, Ghizan B Saleh, Mahmoodreza Shabanimofrad and Latifl, M.A. (2012). Phenotypic and genetic variation of Jatropha curcas L populations from different countries. Maydica, 57:164-174.

Biswas, P.K., V. Pohit and Kumar, R. (2010). Biodiesel from Jatropha: Can India meet the $20 \%$ blending target? Energy Policy, 38:1477-1484.

Burton, G.W. (1952). Quantitative inheritance in grasses. Proceeding of $7^{\text {th }}$ Intl. Grassland Cong. 277-283.

Das, S., R.C. Misra, A.K. Mahapatra, B.P. Gantayat and Pattnaik, R. K. (2010). Genetic Variability, Character Association and Path Analysis in Jatropha curcas. World Applied Science Journal, 8 (11): 1304-1308.

Freitas R.G., R.F. Missio, F.S Matos, M. D. V. and Resende Dias, L.A.S. (2011). Genetic evaluation of Jatropha curcas: an important oilseed for biodiesel production. Genetics and Molecular Research, 10(3): 1490-1498.

Johnson, H.W., H. F. Robinson and Comstock, R.E. (1955). Estimates of genetic and environmental variability in soybean. Agronomy Journal, 47:314-318.

Kaushik, N., K. Kumar, S. Kumar and Roy, S. (2007). Genetic variability and divergence studies in seed traits and oil content of Jatropha (Jatropha curcas L.) accessions. Biomass and Bioenergy, 31:497-502. 
Kheira, A.A.A. and Atta, N.M.M (2009). Response of Jatropha curcas L. to water deficits: Yield, water use efciency and oil seed characteristics. Biomass and Bioenergy, 33:1343-1350.

Lush J.L. (1949). Heritability of quantitative characters in farm animals, Proc. $8^{\text {th }}$ Intl. Genetic Cong. Hereditas (Supp.), 356-357.

Mishra, D.K.(2009). Selection of candidate plus phenotypes of Jatropha curcas L. using method of paired comparisons. Biomass and Bioenergy, 33:542-545.

Nath, Anmika, P.A. Tajane, Taruna Amrawat and Meena A. K. (2014). Genetic variability studies in Jatropha (Jatropha curcas L.). International Journal of Plant Sciences, 9:330-332.

Panse, V.G.and Sukhatme, P.V. (1978). Statistical methods for agricultural workers, ICAR, New Delhi.

Rafii1, M.Y., I.W. Arolu, M.H.A. Omar and Latif, M.A. (2012).Genetic variation and heritability estimation in Jatropha curcas L. population for seed yield and vegetative traits. Journal of Medicinal Plants Research, 6(11): 2178-2183.

Rajgopal, D. and Zilber - man, D. (2007). Review of environmental, economic and policy aspects of biofuels. World Bank Policy Research Working Paper No. 4341
Rao, G.R., G.R. Korwar, A.K. Shanker and Ramakrishna, Y.S. (2008). Genetic associations, variability and diversity in seed characters, growth, reproductive phenology and yield in Jatropha curcas (L.) accessions. Trees, 22:697-709.

Rosch, C. and Skarka, J. (2009). The European biofuels policy and sustainability p. 31-35 In: International Association for Energy Economics.

Ruth, L. (2008). Bio or bust? Te economic and ecological cost of biofuels. EMBO-reports 9:130-133.

Singh, Rekha, R.M. Pandey and Singh Bajrang. (2013). Genetic association, divergence and variability studies for seed yield and oil content and its contributing traits in Jatropha (Jatropha curcas L.). Journal of Medicinal Plants Research, 7: 1931-1939.

Spark, D.N. (1973). Euclidean cluster analysis Algorithm. Applied Statics, 22: 126-130.

Sunil, N., K.S. Varaprasad, N. Sivaraj, T.S. Kumar, B. Abraham and Prasad, R.B.N. (2008). Accessing Jatropha curcas L. germplasm in-situ - A case study. Biomass and Bioenergy, 32:198-202,

Tefera, H., Assefa, K., Hundera, F., Kefyalew T. and Teferra T. (2003). Heritability and genetic advance in recombinant inbred lines of tef (Eragrostis tef). Euphytica, 131:91-96. 